\title{
Intraocular Pressure Effects of Common Topical Steroids for Post-Cataract Inflammation: Are They All the Same?
}

\author{
Uwe Pleyer • Paul G. Ursell • Paolo Rama
}

To view enhanced content go to www.ophthalmology-open.com

Received: July 18, 2013 / Published online: September 17, 2013

(C) The Author(s) 2013. This article is published with open access at Springerlink.com

\section{ABSTRACT}

The efficacy of topical corticosteroids as ocular anti-inflammatory agents following cataract surgery is well-documented. They also help to prevent a number of complications associated with post-operative ocular inflammation, including corneal edema and cystoid macular edema. However, topical corticosteroids are associated with side effects, such as increased intraocular pressure (IOP). Indeed, corticosteroid-induced ocular hypertension

\footnotetext{
U. Pleyer $(\square)$

Department of Ophthalmology, University

Medicine Charité, Humboldt University,

Charitéplatz 1, 10117 Berlin, Germany

e-mail: Uwe.pleyer@charite.de

P. G. Ursell

Epsom and St Helier University NHS Trust,

Epsom, Surrey, UK

P. Rama

Cornea and Ocular Surface Unit, San Raffaele

Scientific Institute, Milan, Italy
}

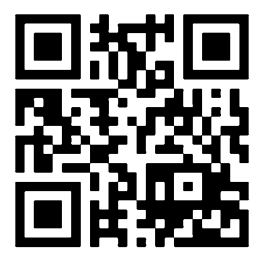

Enhanced content for this article is available on the journal web site: www.ophthalmology-open.com and the potential for steroid-induced glaucoma remain the leading drawbacks of topical corticosteroid therapy. Some individuals are known to experience a high degree of IOP elevation with low doses or short durations of treatment with topical corticosteroids. Careful monitoring of IOP in such individuals is essential. Few randomized, controlled studies are available on the comparative safety and efficacy of common topical corticosteroids in the treatment of post-operative ocular inflammation. Furthermore, the lack of consistent reporting criteria for clinically significant IOP increases across clinical studies makes meaningful comparisons among corticosteroids difficult. This review aims to examine data from available published studies, including studies in steroid responders, to determine whether topical corticosteroids are the same in terms of their effect on IOP. Early generation corticosteroids, such as dexamethasone and prednisolone, are more likely to result in clinically significant increases in IOP. Newer corticosteroids, such as rimexolone and the retro-metabolically designed corticosteroid, loteprednol etabonate, offer similar anti-inflammatory efficacy to older 
corticosteroids with less effect on IOP. However, randomized controlled trials of newer corticosteroids are needed. The proportion of patients exhibiting an increase of $\geq 10 \mathrm{mmHg}$ IOP in clinical studies has emerged as the most clinically relevant parameter for ophthalmologists to consider when deciding on which topical corticosteroid to use.

Keywords: Cataract surgery; Corticosteroids; Inflammation; Intraocular pressure; Ophthalmology; Topical treatment

\section{INTRODUCTION}

Surgical trauma to the eye initiates an inflammatory reaction. This reaction includes the release of prostaglandins and the recruitment of neutrophils and macrophages to the site of trauma [1]. Although usually selflimited, post-operative ocular inflammation after cataract surgery can be associated with complications, including corneal edema, spikes in intraocular pressure (IOP), cystoid macular edema (CME), and posterior capsule opacification [1]. As most patients expect $20 / 20$ vision after cataract surgery without any complications, the use of prophylactic anti-inflammatory agents is a standard practice.

Topical corticosteroids are routinely used in the treatment of post-operative inflammation following cataract surgery [2-5] as well as after most other ocular surgical procedures [6-9]. Corticosteroids reduce intraocular inflammation, which is most often measured by anterior segment cell and flare reaction. They also alleviate associated symptoms, such as photophobia, swelling, pain, and tenderness. At a histological level, corticosteroids suppress cellular infiltration, capillary dilation, the proliferation of fibroblasts, collagen deposition, and eventually scar formation [10]. At a cellular level, they stabilize intracellular and extracellular membranes, and increase the synthesis of anti-inflammatory lipocortins. Lipocortins, in turn, block phospholipase $\mathrm{A}_{2}$, the enzyme responsible for conversion of phospholipids to arachidonic acid, the first step in the inflammatory cascade (Fig. 1) [11-13]. Corticosteroids mediate their antiinflammatory effects primarily through the glucocorticoid receptor by direct and indirect actions at the genomic level [14]. Recent work suggests that the activated corticosteroidreceptor complex also elicits nongenomic effects, particularly in the inhibition of vasodilation, vascular permeability, and migration of leukocytes [14].

Although topical ocular corticosteroids are a vital component of the treatment of postoperative inflammation, their prolonged use can produce side effects, such as increased IOP, cataract formation (in phakic individuals), and lowered resistance to infection [1, 11, 15-17]. Research shows that elevated IOP, if left untreated, may lead to progressive optic nerve damage and glaucomatous visual field defects, ultimately culminating in corticosteroid-induced glaucoma [18]. The mechanism whereby topical corticosteroids increase IOP is not fully

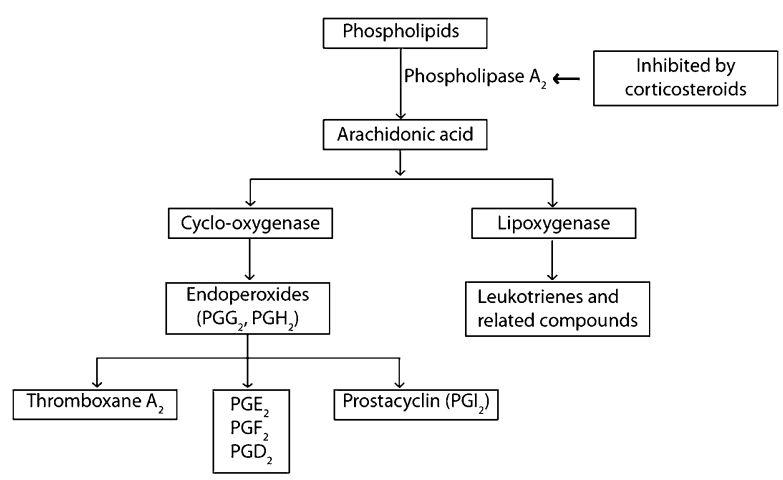

Fig. 1 The inflammatory pathway. $P G$ prostaglandin 
understood. The glucocorticoid receptor is involved in multiple, diverse signaling pathways, and it is thought that steroidinduced IOP elevation, particularly that observed with long-term use or high doses of corticosteroids, is the result of upregulation or repression of one or more genes unrelated to the indication being treated [19]. Most studies implicate trabecular meshwork (TM) cells and myocilin gene expression in the mechanism of corticosteroid-induced IOP elevation. Corticosteroids appear to decrease the outflow of aqueous humor by inhibiting the degradation and/or enhancing the deposition of extracellular matrix material within the TM and/or cross-linking of actin fibers between TM cells [20]. The TM accounts for the majority of drainage from the eye; it appears to be this resistance to aqueous outflow (caused by changes to the TM and its extracellular matrix) that eventually leads to an increase in IOP. Indeed, early ultrastructural studies revealed an increase in extracellular ground substance of the corneo-scleral trabeculum in steroidinduced glaucoma [21]. Clark and Wordinger [22] suggested that structural changes in the $\mathrm{TM}$, in turn, result in corticosteroid-induced ocular hypertension, which can progress to secondary iatrogenic open-angle glaucoma. Myocilin, initially referred to as TM-inducible glucocorticoid response or TIGR gene product, is a $55-\mathrm{kDa}$ protein induced after exposure of $\mathrm{TM}$ cells to dexamethasone for 2-3 weeks, which is also closely associated with decreased aqueous humor outflow and steroid-induced IOP increase [23, 24]. Different mutations within the myocilin gene lead to a variety of glaucoma phenotypes in both juvenile and adult-onset primary open-angle glaucoma, providing further evidence for its role in steroid-induced IOP. Fan et al. [25] compared the effects of triamcinolone acetonide and dexamethasone on the differential gene expression profile of human TM cells and found that both steroids induced or repressed the same genes, suggesting a common mechanism for steroid-induced ocular hypertension at the cellular level. It follows that any differences among topical corticosteroids in IOP effects are influenced by differences in ocular tissue penetration and half-life. Figure 2 [26] explores the proposed mechanism of action of corticosteroid-induced IOP elevation; however, further research into the details surrounding this mechanism of action is certainly warranted.

The objective of this article was to review differences in IOP effects among common topical ophthalmic corticosteroids used to treat inflammation following cataract surgery.

\section{METHODS}

Publications were identified through a search of MEDLINE/PubMed from 1946 to 2013 using any of the terms "anti-inflammatory agents," "androstadienes," "pregnadienes," "glucocorticoid drug," "corticosteroids," and "glucocorticoids," then limited to those results including the terms "cataract extraction" or "cataract surgery" and then "IOP" or "intraocular pressure." Results were limited to only those studies conducted in humans and reported in English. In addition, a few studies specifically examining corticosteroid-induced changes in IOP in those individuals with previously documented steroid response were identified to provide a perspective on the IOP effects of steroids in responders. Overall, randomized, controlled clinical studies using prednisolone, dexamethasone, fluorometholone, loteprednol etabonate, rimexolone, and difluprednate formed the vast majority of these results. We focused on data from studies 


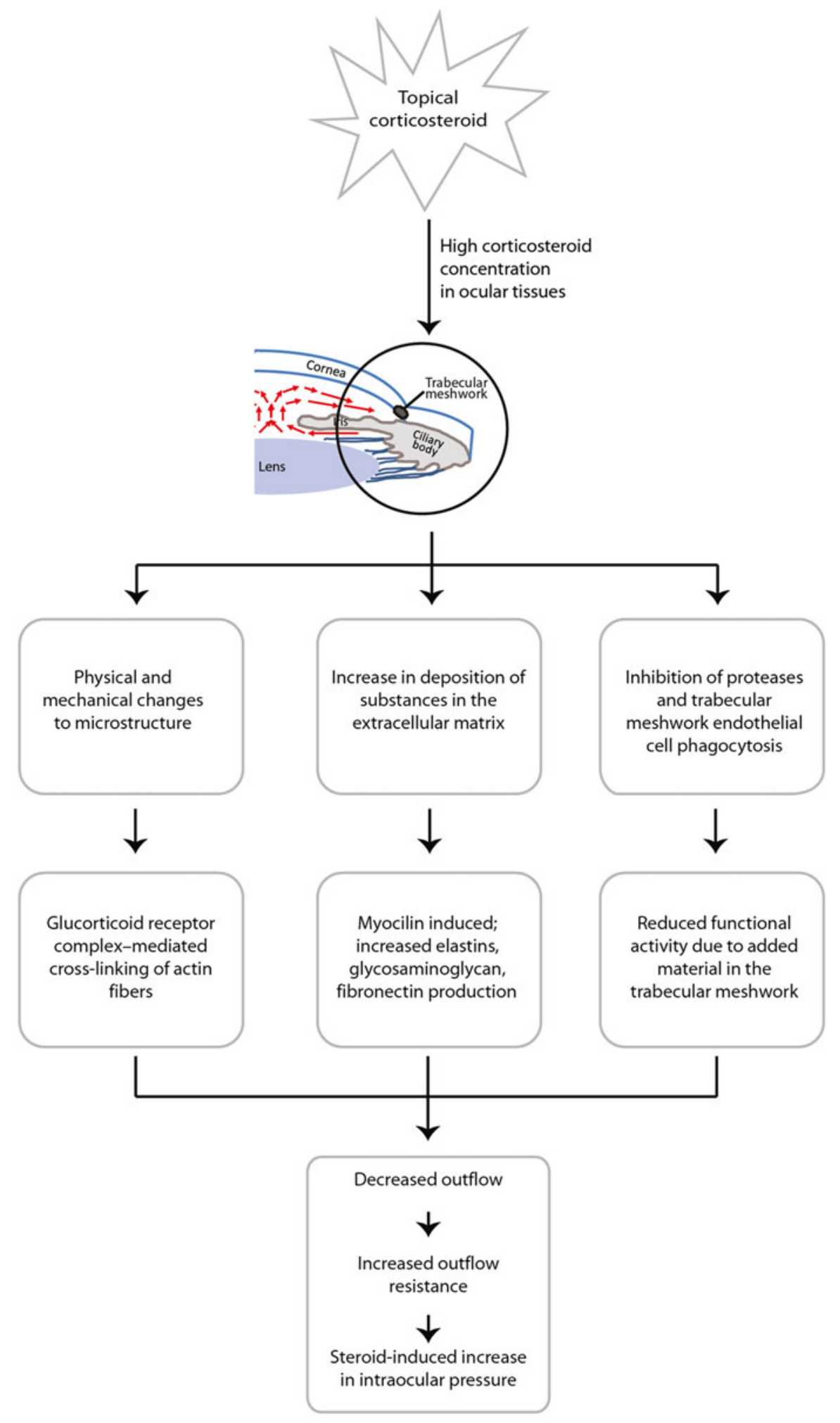

Based on information from [26]

Fig. 2 Proposed mechanism of action of corticosteroid-induced increase in intraocular pressure 
on loteprednol etabonate, rimexolone, and difluprednate because these three drugs have been formally approved by the United States Food and Drug Administration (FDA) and in various European and Asian countries for the specific indication of post-operative inflammation. We also reviewed the older corticosteroids prednisolone, dexamethasone, and fluorometholone because these are still commonly used. Although the primary focus was on topical corticosteroids used in the treatment of post-operative ocular inflammation after cataract surgery, other indications were included if these provided relevant IOP findings.

\section{TOPICAL OCULAR}

\section{CORTICOSTEROIDS: DIFFERENCES IN REPORTING INTRAOCULAR PRESSURE EFFECTS ACROSS STUDIES}

As indicated previously, while the efficacy of topical ocular corticosteroids in the treatment of ocular inflammation has been shown, they also have the potential of increasing IOP $[1,11$, $13,15,16,19,27-31]$. However, to date, meaningful comparisons of the potential for corticosteroid-induced increase in IOP with different corticosteroids have been hampered by a lack of a standard format for testing and reporting clinically significant IOP elevations [18]. In the mid-1960s, Becker used absolute IOP as the criterion, with $20 \mathrm{mmHg}$ being the lower limit of a clinically significant response, while Armaly $[32,33]$ classified the IOP response as a relative difference (treated vs. untreated eye), with a difference of $6 \mathrm{mmHg}$ being the lower limit of a clinically significant response. In 1984, Stewart et al. [34] conducted a study comparing the ocular pressure effects of fluorometholone acetate and dexamethasone sodium phosphate in steroid responders, and proposed that an increase in IOP of $\geq 10 \mathrm{mmHg}$ over baseline should be considered clinically significant. This value was readily accepted by the ophthalmic community; it has since been adopted by the United States FDA, and many subsequent studies have associated an increase in IOP of $\geq 10 \mathrm{mmHg}$ over baseline with clinical significance [2, 4, 5, 35-40]. Nonetheless, many relatively recent studies still fail to report this outcome. Below, we review published studies on topical ophthalmic corticosteroids used in post-operative inflammation, noting any reports of IOP elevations of $\geq 10 \mathrm{mmHg}$ where available.

\section{Older Corticosteroids}

Because early generation corticosteroids, including dexamethasone, prednisolone, and fluorometholone, were introduced prior to current regulatory requirements, pivotal placebo-controlled clinical trials are lacking. However, a few recent comparative studies were found in the literature and provide an insight to their IOP effects.

Saari et al. [41] compared the antiinflammatory effects of $0.7 \%$ dexamethasonecyclodextrin aqueous solution instilled once daily and $0.1 \%$ dexamethasone sodium phosphate instilled three-times daily in 20 patients undergoing cataract surgery. Patients were randomized to receive study treatment post-operatively and were assessed on postoperative days $1,3,7$, and 21 . Laser flare cell meter measurements showed that on postoperative day 21 patients treated with $0.7 \%$ dexamethasone-cyclodextrin demonstrated lower mean post-operative photon count and mean cell count $(P \leq 0.032)$ than those treated with dexamethasone sodium phosphate. No significant differences in the mean [standard 
deviation (SD)] IOP were observed between treatment groups $\left[\begin{array}{lllll}14.0 & (3.1) & \text { vs. } & 14.3 & (2.1)\end{array}\right.$ $\mathrm{mmHg}$ at final visit] [41]. However, IOP elevations of $\geq 10 \mathrm{mmHg}$ over baseline were not reported. Laurell and Zetterstrom [30] compared the effects of treatment with dexamethasone, diclofenac, or placebo in 180 patients after phacoemulsification and intraocular lens (IOL) implantation. Inflammation was measured by laser flare photometry pre-operatively and at 1,3 , and 8 days, 2 and 4 weeks, 2 and 6 months, and 1, 2, and 4 years post-operatively. Dexamethasone and diclofenac were more efficacious than placebo and were equally efficacious in the reduction of post-operative inflammation. At post-operative day 8 and 1 month, a significantly higher mean IOP was observed in the dexamethasone group when compared with the placebo group (16 vs. $13 \mathrm{mmHg}$ at day 8 , and 15 vs. $14 \mathrm{mmHg}$ at 1 month, respectively; $P<0.05$ for both). The authors reported that no patient exhibited an increase in IOP of $\geq 10 \mathrm{mmHg}$ [30].

Lorenz et al. [42] studied the effects of prednisolone acetate $0.5 \%$ on intraocular inflammation after phacoemulsification. Prednisolone acetate $0.5 \%$ or placebo was instilled in 62 patients four-times daily until day 2 post-operatively. All patients were then treated with open-label prednisolone acetate $0.5 \%$ administered four-times daily until day 14. A significant difference between prednisolone acetate and placebo was observed on post-operative day 3 in protein flare (20.8 vs. 32.6 photon counts $/ \mathrm{ms}$ respectively; $P=0.0055)$ while flare measures were comparable at day 14 (13.0 and 11.4 photon counts/ms, respectively). Increased IOP (degree of increase not reported) was observed in three patients (4.8\%), although mean IOP was considered normal $(<21 \mathrm{mmHg})$ in both groups at the end of the treatment period [42]. Smerdon et al. [43] compared the efficacy and safety of prednisolone $0.5 \%$ with placebo (vehicle) in the control of inflammation following cataract extraction in 120 patients. Treatment with tolmetin $2 \%$ was included in the study as the third treatment arm. Treatments were administered four-times daily for 6 weeks. Resolution of post-operative inflammation was reported for a significantly higher proportion of patients in the prednisolone group compared to the placebo group ( $94 \%$ vs. $46 \%$, respectively; $P<0.001$ ). Seven patients (24\%) in the prednisolone group when compared with three patients $(9 \%)$ in the placebo group had IOP elevated to $>22 \mathrm{mmHg}$ during the trial. However, the authors did not report whether any IOP elevations were $\geq 10 \mathrm{mmHg}$ above baseline.

Our literature search failed to identify randomized, placebo-controlled studies of fluorometholone in post-cataract surgery. However, Trinavarat et al. [44] compared the efficacy and adverse effects of prednisolone acetate $0.5 \%$, ketorolac tromethamine $0.5 \%$ and fluorometholone acetate $0.1 \%$ in patients with post-operative inflammation following cataract surgery. A total of 120 eyes were enrolled in this prospective, investigatormasked, randomized controlled trial with each drug administered four-times daily for 4 weeks. All treatments were effective in the primary outcome measure-reducing inflammation after phacoemulsification. Mean IOP was higher in the prednisolone group when compared with the ketorolac group on day 21 (14.6 vs. $12.2 \mathrm{mmHg}$, respectively; $P=0.016$ ) but did not differ from the fluorometholone group (13.8 $\mathrm{mmHg})$. One eye in the prednisolone group had an IOP of $32 \mathrm{mmHg}$ on day 21 and was terminated from the study. Vetrugno et al. [45] compared the efficacy and 
tolerability of fluorometholone $0.1 \%$ acetate and fluorometholone $0.2 \%$ in two groups of 30 patients who had undergone myopic photorefractive keratectomy. Patients instilled treatments four-times daily for 1 month, followed by treatment application at decreasing frequency every 3 weeks. No significant differences were observed in visual acuity, haze, and mean IOP between the two groups, although mean IOP increased relative to baseline in both groups. Three patients in the fluorometholone $0.2 \%$ group and two patients in the fluorometholone acetate $0.1 \%$ group had increased IOP at 15 and 30 days (fluorometholone $\quad 0.2 \%$ group: 28, 31, $26 \mathrm{mmHg}$; fluorometholone $0.1 \%$ acetate group: 27, $26 \mathrm{mmHg}$ ). The authors did not report whether any of these elevations were $\geq 10 \mathrm{mmHg}$ over baseline, but indicated that IOP-lowering medication was administered.

While these studies demonstrate the efficacy of older corticosteroids for post-operative inflammation, safety findings suggest potential IOP effects with all three corticosteroids. The lack of consistent IOP reporting precludes more meaningful comparisons across these studies.

\section{Newer Corticosteroids}

Rimexolone, difluprednate, and loteprednol etabonate are relatively recent ophthalmic corticosteroids introduced during today's more comprehensive regulatory environment. Hence, pivotal placebo-controlled clinical trials, as well as comparative trials for these steroids are available in the literature. Table $1[2-5,40$, 46-48] summarizes comparative rates of resolution of inflammation and clinically significant increases in IOP observed with each of these three newer corticosteroids in placebocontrolled trials.
Rimexolone is a highly lipophilic glucocorticoid that lacks a hydroxyl substituent at the 21-position of the core corticosteroid structure [49, 50]. Foster et al. [37] suggested that the lipophilicity of rimexolone results in a balance between efficacy and safety. Specifically, rimexolone is thought to achieve ocular tissue levels sufficient to treat inflammation, while its limited ocular penetration and biological half-life minimize any IOP effects [37]. Bron et al. [3] examined the efficacy and safety of a 2-week regimen of rimexolone $1 \%$ as compared to placebo in reducing post-operative inflammation in 182 post-cataract patients. The proportion of patients showing resolution of anterior chamber inflammation (ACI) was 50\% and $21.1 \%$ for the rimexolone and placebo groups, respectively $(P=0.0003)$, on post-operative day 15. Rimexolone-treated patients had significantly less bulbar conjunctival erythema, corneal edema, anterior vitreous reaction, and ocular discomfort $(P<0.05)$. No perceptible changes in IOP were reported for either group, but the authors noted that the study was not designed to show differences in IOP response. Assil et al. [46] also compared rimexolone to placebo for post-operative inflammation in 196 post-cataract patients. ACI was completely resolved in $59.7 \%$ and $19.6 \%$ of patients in the rimexolone and placebo groups, respectively, on day 15 post-operatively. There was no between-group difference in mean (SD) IOP on day 15 [15.7 (4.7) and 14.9 (3.3) $\mathrm{mmHg}$ in the rimexolone and placebo groups, respectively; $P=0.32$ ]. However, two patients in each group exhibited an increase in IOP of $\geq 10 \mathrm{mmHg}$ over baseline.

Yaylali et al. [51] compared the efficacy and safety of rimexolone $1 \%$ to prednisolone acetate $1 \%$ in 48 post-cataract patients. Treatments were administered four-times daily for 15 days 





post-operatively, and patients were examined on post-operative days $1,3,7$, and 15 . Anterior chamber cell and flare, and conjunctival hyperemia were the main efficacy parameters; IOP was assessed as a safety parameter. Across all efficacy parameters, rimexolone was equivalent to prednisolone acetate $1 \%$, with the exception of mean (SD) number of anterior chamber cells at day 3 [0.55 (0.5) vs. 0.19 (0.40), respectively; $P=0.01]$. Post-operative IOP values were also similar between treatment groups, with the exception of day 3, on which the mean (SD) IOP was found to be higher in the prednisolone

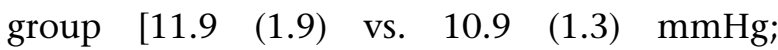
$P=0.038]$. IOP increases $\geq 10 \mathrm{mmHg}$ from baseline were not reported. Kavuncu et al. [52] also compared the efficacy and safety of rimexolone $1 \%$ with that of prednisolone acetate $1.0 \%$. Patients $(n=80)$ undergoing cataract extraction with IOL implantation were randomized to receive either prednisolone acetate or rimexolone every $4 \mathrm{~h}$ for 18 days. There were no differences between treatments in anterior chamber cell count or flare. Treatment with rimexolone was associated with higher conjunctival hyperemia on days 1 and $3 \quad(P<0.05)$, while treatment with prednisolone acetate was associated with higher corneal edema on day $8 \quad(P<0.05)$. There were no between-treatment differences in the mean IOP at any visits, with IOP ranging from 11.1 to 14.0 and $10.5-14.7 \mathrm{mmHg}$ in the prednisolone acetate and rimexolone groups, respectively.

Difluprednate, a derivative of prednisolone that is difluorinated at the $\mathrm{C} 6$ and $\mathrm{C} 9$ positions [4], is approved for treating post-operative inflammation in the United States and some countries in the European Union. Originally developed for dermatologic applications, it was also found to rapidly penetrate the corneal epithelium [4]. Korenfeld et al. [4] compared the efficacy and safety of difluprednate ophthalmic emulsion $0.05 \%$ with that of placebo (vehicle) in 438 patients with inflammation after ocular surgery in two studies. Difluprednate and placebo were instilled twice daily in one study and fourtimes daily in the other. Both difluprednate regimens were effective in reducing pain and inflammation post-operatively as compared to placebo. The proportion of patients with resolution of anterior chamber cells (grade 0 cells) on day 8 was $30 \%, 35 \%$, and $9 \%$ in the difluprednate group with the twice-daily dose regimen, difluprednate group with the fourtimes daily dose regimen, and the pooled placebo group, respectively $(P<0.0001$ vs. placebo for both difluprednate regimens). However, $3 \%$ of patients in both difluprednate groups exhibited an increase in IOP of $\geq 10 \mathrm{mmHg}$ from baseline to an IOP of $\geq 21 \mathrm{mmHg}$ as compared to $1 \%$ of patients in the placebo group. Smith et al. [40] also compared the efficacy and safety of difluprednate ophthalmic emulsion $0.05 \%$ with that of placebo (vehicle) in 121 patients undergoing cataract surgery. In this study, dosing was initiated $24 \mathrm{~h}$ before surgery and consisted of twice-daily administration for 16 days, followed by a 14-day tapering period. Resolution of ACI (anterior cells grade, 0; flare grade, 0) on day 14 was higher among patients in the difluprednate group than in the placebo group $(74.7 \%$ vs. $42.5 \%, P=0.0006)$. Again, three patients (3.7\%) in the difluprednate group had an increase in IOP of $\geq 10 \mathrm{mmHg}$ from baseline to an IOP of $\geq 21 \mathrm{mmHg}$ as compared with none of the patients in the placebo group.

The IOP-increasing potential of difluprednate was further investigated by Cable in a retrospective chart review [53]. Data from 100 consecutive, uncomplicated phacoemulsification patients treated with 
difluprednate ophthalmic emulsion $0.05 \%$ twice daily post-operatively were analyzed. Five percent of patients, all with a history of open-angle glaucoma, responded with ocular hypertension. The average increase in IOP among responders was $17.8 \mathrm{mmHg}$, considerably higher than the accepted value for a clinically significant increase $(\geq 10 \mathrm{mmHg})$. Moreover, $60 \%$ of IOP elevations were noted on post-operative day 1 and a further $40 \%$ on postoperative day 7 . The authors concluded that difluprednate administered twice daily could cause significant and early elevations in IOP.

Loteprednol etabonate is approved for the treatment of post-operative inflammation in the United States and most countries in the European Union. Loteprednol etabonate differs from other ophthalmic corticosteroids in that it has an ester rather than a ketone at the C-20 position of the core corticosteroid structure [54]. Loteprednol etabonate was designed through retro-metabolic drug design; a process by which an inactive, non-toxic metabolite of a reference compound, in this case prednisolone, is chemically modified to a therapeutically active compound [55, 56]. Clinically, following ocular penetration and saturation of the glucocorticoid receptor in ocular tissues, unbound loteprednol etabonate undergoes rapid de-esterification to its inactive metabolite, $\Delta^{1}$ cortienic acid etabonate, or PJ-91, resulting in a decreased impact on IOP $[39,56-58]$. The efficacy and safety of loteprednol etabonate $0.5 \%$ suspension in post-operative inflammation were demonstrated in two placebo-controlled studies ( $n=227$ and $n=203$, respectively) [2, 5]. In both studies, patients were randomized to either loteprednol etabonate $0.5 \%$ or vehicle four-times daily for up to 14 days after cataract surgery. In the first study, ACI was resolved in $64 \%$ and $29 \%$ of patients in the loteprednol etabonate and vehicle groups, respectively; while in the second study, ACI was resolved in $55 \%$ and $28 \%$ of patients, respectively $(P<0.001$ for both studies) at post-operative day 15. A post hoc analysis of pooled data from both studies showed that pain was resolved in $84 \%$ and $56 \%$ of patients with baseline pain scores of $>0$ for the loteprednol etabonate and vehicle groups, respectively $(P<0.05)$ [59]. In both studies, there was an overall mean decrease in IOP of $1-2 \mathrm{mmHg}$ for the loteprednol etabonate- and vehicle-treated patients at all post-operative visits relative to screening, with no significant differences between the treatment groups in either study. A clinically significant increase in IOP ( $\geq 10 \mathrm{mmHg}$ ) over baseline was observed in three patients in the loteprednol etabonate group in the first study and in one patient receiving the vehicle in the second study.

Lane and Holland compared the efficacy and safety of loteprednol etabonate $0.05 \%$ with that of prednisolone acetate $1.0 \%$ (Pred Forte ${ }^{\circledR}$, Allergan, Inc., Irvine, CA, USA), administered four-times daily in 88 patients following routine cataract surgery and found similar control of inflammation after surgery [60]. At postoperative days $1,3,7$, and 21 , mean IOP and mean change in IOP were higher in patients treated with prednisolone acetate than in those treated with loteprednol etabonate, although this did not reach statistical significance. One patient in the prednisolone acetate treatment group had a clinically significant increase in IOP ( $\geq 10 \mathrm{mmHg}$ ) over baseline.

Fong et al. and Rajpal et al. $[47,48]$ recently examined the efficacy and safety of a gel formulation of loteprednol etabonate as compared to vehicle (both dosed four-times a day) in reducing post-operative inflammation and pain in post-cataract patients $(n=407$ and $n=406$, respectively). The gel contains $0.5 \%$ 
loteprednol etabonate in a non-settling formulation intended to provide consistent dose uniformity without the need to shake. In both multicenter, randomized, masked studies a greater proportion of loteprednol etabonate-treated patients had complete resolution of anterior chamber cells on Day 8 as compared to vehicle-treated patients $(31.1 \%$ vs. $13.9 \%$ and $30.5 \%$ vs. $16.3 \%$, respectively; $P<0.001$ for both). Similarly, a greater proportion of loteprednol etabonate-treated patients had grade 0 pain $(75.7 \%$ vs. $45.8 \%$ and $72.9 \%$ vs. $41.9 \%$, respectively, $P<0.001$ for both). In both studies mean IOP was consistently lower than baseline for both treatment groups at follow-up visits. Two patients in the loteprednol etabonatetreatment group and one patient in the vehicle group exhibited a clinically significant increase from baseline in IOP $(\geq 10 \mathrm{mmHg})$ across the two studies.

Low incidences of elevated IOP ( $\geq 10 \mathrm{mmHg}$ ) have also been observed in studies of loteprednol etabonate suspension in the treatment of giant papillary conjunctivitis, seasonal allergic conjunctivitis, anterior uveitis, and delayed tear clearance [35, 61-64] or when loteprednol etabonate was used in combination with tobramycin in the treatment of blepharokeratoconjunctivitis [65-68]. Novack et al. [69] further examined the IOP data from all patients enrolled in loteprednol etabonate development trials in the United States who received treatment for a period of $\geq 28$ days, and found that loteprednol etabonate had minimal effect on IOP when used long term. Of patients who received loteprednol etabonate $0.5 \%$ or $0.2 \%, \quad 1.7 \% \quad(15 / 901)$ exhibited IOP elevations of $\geq 10 \mathrm{mmHg}$ over baseline as compared with $6.7 \%(11 / 164)$ of patients who were treated with prednisolone acetate $1.0 \%$. Among patients using loteprednol etabonate $\quad 0.5 \%$, only $2.1 \%$

$(14 / 664)$ demonstrated clinically significant increases in IOP; this proportion was reduced to $0.8 \%$ (3/387) when patients who continued to wear contact lenses during treatment were eliminated, suggesting that contact lenses might potentially act as reservoirs for corticosteroids [69].

Taken together, the above studies indicate that the newer corticosteroids, i.e., rimexolone, difluprednate, and loteprednol etabonate, offer similar efficacies in terms of resolution of postoperative inflammation. However, fewer clinically significant increases in IOP appeared to be associated with rimexolone and loteprednol etabonate use when compared with difluprednate use, likely due to ocular pharmacokinetic differences among these steroids. Further comparative studies are needed, however. The most clinical data on IOP effects was found for loteprednol etabonate and suggested little effect on IOP associated with loteprednol etabonate.

\section{STUDIES IN STEROID RESPONDERS}

Some patients have a documented history of IOP increase in response to corticosteroid treatment, in which a small dose of corticosteroid or a short duration of treatment may result in disproportionate increases in IOP. First documented by Armaly and Becker in the 1960s [32, 70, 71], steroid responders generally constitute $18-36 \%$ of the general population [19]. Corticosteroid effects on IOP in such patients are generally reversible; IOP will usually return to pretreatment levels within 1-3 weeks if the treatment is discontinued [72]. Nevertheless, careful monitoring of IOP is essential in such individuals. Longer axial length has been identified as a risk factor for steroid-induced IOP elevation [28]. In addition, 
Table 2 Mean increase in intraocular pressure observed with topical corticosteroids in steroid responders $(n=10)$

\begin{tabular}{llc}
\hline Preparation & $\begin{array}{l}\text { Final IOP } \\
(\text { mean } \mathbf{~ m m H} \pm \mathbf{S E})\end{array}$ & $\begin{array}{c}\text { Average IOP increase } \\
\text { (mean mmHg SE) }\end{array}$ \\
\hline Dexamethasone 0.1\% & $45.1 \pm 2.7$ & $22.0 \pm 2.9$ \\
Prednisolone 1.0\% & $32.3 \pm 2.1$ & $10.0 \pm 1.7$ \\
Dexamethasone 0.005\% & $31.3 \pm 2.4$ & $8.2 \pm 1.7$ \\
Fluorometholone 0.1\% & $29.2 \pm 2.2$ & $6.1 \pm 1.4$ \\
Hydrocortisone 0.5\% & $26.3 \pm 1.5$ & $3.2 \pm 1.0$ \\
Tetrahydrotriamcinolone 0.25\% & $24.9 \pm 1.8$ & $1.8 \pm 1.3$ \\
Medrysone 1.0\% & $24.1 \pm 1.8$ & $1.0 \pm 1.3$ \\
\hline
\end{tabular}

Adapted from [73]

$I O P$ intraocular pressure, $S E$ standard error

patients with primary open-angle glaucoma, family history of glaucoma and status as a glaucoma suspect are also at higher risk for developing corticosteroid-induced ocular hypertension [26, 67]. Most prospective studies reviewed in the previous sections would have excluded known steroid responders, as the risk of developing a clinically significant change in IOP would have been considered too high. However, several published studies report on the corticosteroid-induced IOP response in known steroid responders. These studies are extremely valuable in differentiating the relative IOP effects among corticosteroids as any differences will be more pronounced in this study population.

Cantrill et al. [73] assessed the IOP-raising potential of various topical corticosteroids in 10 known steroid responders. Steroid responders were defined as those patients who developed IOP of $>31 \mathrm{mmHg}$ after topical application of dexamethasone $0.1 \%$ administered four-times daily for 2-6 weeks. Patients were sequentially tested with dexamethasone phosphate $0.005 \%$, medrysone $1 \%$, tetrahydrotriamcinolone $0.25 \%$, hydrocortisone $0.5 \%$, and prednisolone acetate $1 \%$. Of the various corticosteroids studied, dexamethasone $0.1 \%$ caused the maximum increase in IOP, i.e., a mean [standard error (SE)] increase of 22.0 (2.9) $\mathrm{mmHg}$ (Table 2) [73].

Akingbehin [74] compared the IOP effects of fluorometholone $0.1 \%$ and dexamethasone $0.1 \%$ administered four-times daily for 6 weeks in 15 patients with ocular hypertension or glaucoma by using provocative testing. Thirteen patients (22 eyes) were first provoked with dexamethasone and 6 months later, with fluorometholone. The remaining two patients underwent simultaneous bilateral testing with dexamethasone (right eye) and fluorometholone (left eye). Drops were discontinued if an increase in IOP of $>15 \mathrm{mmHg}$ over baseline was observed. The mean increase in IOP was $8.58 \mathrm{mmHg}$ with dexamethasone treatment as compared to $2.96 \mathrm{mmHg}$ with fluorometholone treatment $(P<0.001)$. Posttreatment IOP elevations of $\geq 10 \mathrm{mmHg}$ were observed in $45.8 \%$ and $4.2 \%$ of the dexamethasone- and fluorometholone-treated eyes, respectively. Stewart et al. [34] also compared the IOP effects of fluorometholone $0.1 \%$ and dexamethasone $0.1 \%$ in patients who had previously experienced an IOP increase of $\geq 10 \mathrm{mmHg}$ with dexamethasone. In this doublemasked, crossover study, 17 patients (17 eyes) 
were dosed sequentially with each of the treatments, with a 1-month between-treatment washout period. Dosing consisted of one drop instilled four-times daily for 6 weeks or until there was an IOP elevation of $\geq 10 \mathrm{mmHg}$. The mean (SE) duration necessary to effect an elevation of $10 \mathrm{mmHg}$ as compared to baseline was 29.5 (3.9) days in the fluorometholone group when compared with 22.7 (3.5) days in the dexamethasone group $(P=0.015)$. As indicated previously, the authors subsequently proposed that an increase in IOP of $\geq 10 \mathrm{mmHg}$ over baseline should be considered clinically significant.

Bartlett et al. [72] challenged 13 healthy volunteers who were first-degree offspring of individuals with primary open-angle glaucoma with topically applied prednisolone phosphate $1 \%$. Subjects were randomized to receive topical prednisolone phosphate $1.0 \%$ in the left eye and placebo in the right eye, or vice versa, for up to 6 weeks. IOP was measured at day 0 (baseline) and at days 7, 14, 21, 28, 35, and 42. After taking into account, the diurnal variation in IOP (by subtracting the IOP in the control eye from that in the treated eye), the authors determined that seven patients (54\%) had maximum IOP elevations of 5-9 $\mathrm{mmHg}$, and two patients (15\%) had IOP elevations of $\geq 10 \mathrm{mmHg}$. The difference in the mean IOP between the treated and control eyes was significant $(P<0.001)$.

The IOP-raising potential of newer corticosteroids in known steroid responders has also been documented. Leibowitz et al. [50] compared the IOP-elevating potential of rimexolone $1.0 \%$ and fluorometholone alcohol $0.1 \%$ in known steroid responders. In this twoway crossover study, responders were defined as those individuals who had exhibited an increase in IOP of $\geq 10 \mathrm{mmHg}$ when challenged for up to 6 weeks with dexamethasone sodium phosphate or prednisolone acetate. After a 1-month washout, responders were administered either study drug (rimexolone or fluorometholone) for a period of 6 weeks or until an increase in IOP of $\geq 10 \mathrm{mmHg}$ was observed, whichever occurred first. This was followed by another 1-month washout period and administration of the alternate study drug under the same conditions. In the 13 responders initially identified through challenge with dexamethasone, the mean IOP elevations were $11.8,7.5$, and $8.4 \mathrm{mmHg}$, for dexamethasone, rimexolone, and fluorometholone, respectively, while in the 20 responders initially identified through challenge with prednisolone acetate, the mean IOP elevations were $12.1,6.2$, and $3.5 \mathrm{mmHg}$ for prednisolone acetate, rimexolone, and fluorometholone, respectively. There was no difference between rimexolone and fluorometholone in mean IOP elevation, the number of patients demonstrating an IOP increase of $\geq 10 \mathrm{mmHg} \quad(30 \%$ vs. $21 \%$, respectively) or mean time to response ( 5.2 vs. 5.4 weeks, respectively). Treatment with rimexolone or fluorometholone resulted in a significantly lower mean IOP elevation as compared to treatment with dexamethasone or prednisolone, and the mean time to IOP elevation was significantly longer than in treatment with dexamethasone or prednisolone (2.5-3 weeks) $(P \leq 0.02$ for all).

Bartlett et al. [16] compared the effects of loteprednol etabonate $0.5 \%$ and prednisolone acetate $1.0 \%$ on IOP in 19 steroid responders defined as individuals who had shown an increase in IOP of $\geq 6 \mathrm{mmHg}$ in $\leq 6$ weeks when treated with topical dexamethasone $0.1 \%$ or prednisolone acetate $1 \%$. Patients instilled one drop of loteprednol etabonate or prednisolone acetate four-times daily for 6 weeks. After a 14-day washout period, 
patients entered the second 6-week phase of the crossover and instilled the alternative study medication. The mean increase in IOP over the 42-day period was 4.1 and $9 \mathrm{mmHg}$ for the loteprednol etabonate group and prednisolone acetate groups, respectively. By day 14, patients in the prednisolone acetate group showed a mean increase in IOP of $5.9 \mathrm{mmHg}$ as compared to baseline $(P<0.05)$. The increase in IOP in patients in the loteprednol etabonate group was not significantly different from baseline.

Finally, Holland et al. [7] reported the attenuation of ocular hypertension in steroid responders after corneal transplantation. In this retrospective review, 30 post-penetrating keratoplasty and post-keratolimbal allograft patients with IOP increases to $\geq 21 \mathrm{mmHg}$, while being treated with prednisolone acetate $1.0 \%$ were switched to loteprednol etabonate $0.5 \%$. Results showed a mean (SE) reduction of IOP from 31.1 (1.13) $\mathrm{mmHg}$ for prednisolone acetate as compared to 18.2 (1.37) $\mathrm{mmHg}$ for loteprednol etabonate $(P=0.0001)$. The authors concluded that loteprednol etabonate could be a good alternative to prednisolone acetate in the prophylaxis of allograft rejection in corneal transplants.

Taken together, these studies in steroid responders confirm a greater effect on IOP, both mean IOP and/or IOP increases of $\geq 10 \mathrm{mmHg}$, with prednisolone acetate and dexamethasone as compared to fluorometholone and rimexolone, and with prednisolone acetate as compared to loteprednol etabonate.

\section{CONCLUSION}

The likelihood of a clinically significant increase in IOP $(\geq 10 \mathrm{mmHg})$ is an important consideration when deciding on which topical corticosteroid is best suited to a patient. Randomized, controlled studies to date, and clinical studies in known steroid responders, indicate that there are significant differences among the common topical ophthalmic corticosteroids used in the treatment of postoperative inflammation: they are not the same in terms of effects on IOP. The available data indicate that dexamethasone and prednisolone acetate, and the newer corticosteroid difluprednate are more likely to result in clinically significant increases in IOP as compared to fluorometholone, rimexolone, and loteprednol etabonate. However, further head-to-head studies comparing the proportion of patients exhibiting clinically significant increases in IOP $(\geq 10 \mathrm{mmHg}$ ) with different corticosteroids, particularly the newer topical ocular corticosteroids, are warranted. In addition, studies assessing the precise mechanism of decreased IOP effect with certain corticosteroids, whether because of rapid metabolism or poor ocular penetration, etc., are also needed. Of the corticosteroid choices currently available, ample published data were found in support of a minimal effect on IOP with loteprednol etabonate, even when studied in known steroid responders.

\section{ACKNOWLEDGMENTS}

Sponsorship and article processing charges for this article were funded by Bausch \& Lomb, Inc. The authors thank Cactus Communications for medical writing services, which was funded by Bausch \& Lomb, Inc. Dr. Uwe Pleyer is the guarantor for this article and takes responsibility for the integrity of the work as a whole. All authors fulfilled authorship criteria as defined by the International Committee of Medical Journal Editors (ICMJE) uniform requirements. The authors critically reviewed the outline and all drafts of this manuscript. 
Conflict of interest. Mr. Paul Ursell is a consultant at Bausch \& Lomb, Inc. Dr. Paolo Rama has no conflicts of interest to declare. Dr. Uwe Pleyer has been a principal investigator/ advisor for Abbott, Alcon, Allergan, Amgen, Bausch \& Lomb, Inc., Bayer/Schering, Centocor, Esba Tech, Essex Pharma, Novartis, Thea, Ursapharm, and Winzer.

Open Access. This article is distributed under the terms of the Creative Commons Attribution Noncommercial License which permits any noncommercial use, distribution, and reproduction in any medium, provided the original author(s) and the source are credited.

\section{REFERENCES}

1. El-Harazi SM, Feldman RM. Control of intra-ocular inflammation associated with cataract surgery. Curr Opin Ophthalmol. 2001;12:4-8.

2. The Loteprednol Etabonate Postoperative Inflammation Study Group 2. A double-masked, placebo-controlled evaluation of $0.5 \%$ loteprednol etabonate in the treatment of postoperative inflammation. The Loteprednol Etabonate Postoperative Inflammation Study Group 2. Ophthalmology. 1998; 105:1780-6.

3. Bron A, Denis P, Hoang-Xuan TC, et al. The effects of rimexolone $1 \%$ in postoperative inflammation after cataract extraction. A double-masked placebocontrolled study. Eur J Ophthalmol. 1998;8:16-21.

4. Korenfeld MS, Silverstein SM, Cooke DL, Vogel R, Crockett RS. Difluprednate ophthalmic emulsion $0.05 \%$ for postoperative inflammation and pain. J Cataract Refract Surg. 2009;35:26-34.

5. Stewart R, Horwitz B, Howes J, Novack GD, Hart K. Double-masked, placebo-controlled evaluation of loteprednol etabonate $0.5 \%$ for postoperative inflammation. Loteprednol Etabonate Postoperative Inflammation Study Group 1. J Cataract Refract Surg. 1998;24:1480-9.

6. Campos M, Avila M, Wallau A, Muccioli C, HöflingLima AL, Belfort R. Efficacy and tolerability of a fixed-dose moxifloxacin-dexamethasone formulation for topical prophylaxis in LASIK: a comparative, double-masked clinical trial. Clin Ophthalmol. 2008;2:331-8.

7. Holland EJ, Djalilian AR, Sanderson JP. Attenuation of ocular hypertension with the use of topical loteprednol etabonate $0.5 \%$ in steroid responders after corneal transplantation. Cornea. 2009;28: 1139-43.

8. Seah SK, Husain R, Gazzard G, et al. Use of surodex in phacotrabeculectomy surgery. Am J Ophthalmol. 2005;139:927-8.

9. Vetrugno M, Maino A, Quaranta GM, Cardia L. The effect of early steroid treatment after PRK on clinical and refractive outcomes. Acta Ophthalmol Scand. 2001;79:23-7.

10. The Loteprednol Etabonate US Uveitis Study Group. Controlled evaluation of loteprednol etabonate and prednisolone acetate in the treatment of acute anterior uveitis. Am J Ophthalmol. 1999;127: $537-44$.

11. Bielory L. Ocular allergy treatment. Immunol Allergy Clin N Am. 2008;28:189-224.

12. McColgin AZ, Heier JS. Control of intraocular inflammation associated with cataract surgery. Curr Opin Ophthalmol. 2000;11:3-6.

13. Simone JN, Whitacre MM. Effects of antiinflammatory drugs following cataract extraction. Curr Opin Ophthalmol. 2001;12:63-7.

14. Rhen T, Cidlowski JA. Antiinflammatory action of glucocorticoids-new mechanisms for old drugs. N Engl J Med. 2005;353:1711-23.

15. Doughty MJ. Ophthalmic corticosteroids: management of the ocular inflammatory response. In: Ocular pharmacology \& therapeutics. London: Butterworth-Heinemann; 2001. p. 92-102.

16. Bartlett JD, Horwitz B, Laibovitz R, Howes JF. Intraocular pressure response to loteprednol etabonate in known steroid responders. J Ocul Pharmacol. 1993;9:157-65.

17. Clark AF, Wilson $\mathrm{K}$, de Kater AW, Allingham RR, McCartney MD. Dexamethasone-induced ocular hypertension in perfusion-cultured human eyes. Invest Ophthalmol Vis Sci. 1995;36:478-89.

18. Spaeth GL, Monteiro de Barros DS, Fudemberg SJ. Visual loss caused by corticosteroid-induced glaucoma: how to avoid it. Retina. 2009;29:1057-61.

19. Tripathi RC, Parapuram SK, Tripathi BJ, Zhong Y, Chalam KV. Corticosteroids and glaucoma risk. Drugs Aging. 1999;15:439-50. 
20. Kersey JP, Broadway DC. Corticosteroid-induced glaucoma: a review of the literature. Eye. 2005;20:407-16.

21. Francois J, Benozzi G, Victoria-Troncoso V, Bohyn W. Ultrastructural and morphometric study of corticosteroid glaucoma in rabbits. Ophthalmic Res. 1984;16:168-78.

22. Clark AF, Wordinger RJ. The role of steroids in outflow resistance. Exp Eye Res. 2009;88:752-9.

23. Nguyen TD, Chen P, Huang WD, Chen H, Johnson $\mathrm{D}$, Polansky JR. Gene structure and properties of TIGR, an olfactomedin-related glycoprotein cloned from glucocorticoid-induced trabecular meshwork cells. J Biol Chem. 1998;273:6341-50.

24. Polansky JR, Fauss DJ, Chen P, et al. Cellular pharmacology and molecular biology of the trabecular meshwork inducible glucocorticoid response gene product. Ophthalmologica. 1997;211: 126-39.

25. Fan BJ, Wang DY, Tham CC, Lam DS, Pang CP. Gene Expression profiles of human trabecular meshwork cells induced by triamcinolone and dexamethasone. Invest Ophthalmol Vis Sci. 2008;49:1886-97.

26. Jones R 3rd, Rhee DJ. Corticosteroid-induced ocular hypertension and glaucoma: a brief review and update of the literature. Curr Opin Ophthalmol. 2006;17:163-7.

27. Chambless SL, Trocme S. Developments in ocular allergy. Curr Opin Allergy Clin Immunol. 2004;4:431-4.

28. Chang DF, Tan JJ, Tripodis Y. Risk factors for steroid response among cataract patients. J Cataract Refract Surg. 2011;37:675-81.

29. Clark AF. Basic sciences in clinical glaucoma: steroids, ocular hypertension, and glaucoma. J Glaucoma. 1995;4:354-69.

30. Laurell CG, Zetterstrom C. Effects of dexamethasone, diclofenac, or placebo on the inflammatory response after cataract surgery. Br J Ophthalmol. 2002;86:1380-4.

31. McGhee CN, Dean S, Danesh-Meyer H. Locally administered ocular corticosteroids: benefits and risks. Drug Saf. 2002;25:33-55.

32. Armaly MF. Genetic factors related to glaucoma. Ann N Y Acad Sci. 1968;151:861-75.

33. Becker B. Intraocular pressure response to topical corticosteroids. Invest Ophthalmol. 1965;4: 198-205.
34. Stewart RH, Smith JP, Rosenthal AL. Ocular pressure response to fluorometholone acetate and dexamethasone sodium phosphate. Curr Eye Res. 1984;3:835-9.

35. Dell SJ, Lowry GM, Northcutt JA, Howes J, Novack GD, Hart K. A randomized, double-masked, placebo-controlled parallel study of $0.2 \%$ loteprednol etabonate in patients with seasonal allergic conjunctivitis. J Allergy Clin Immunol. 1998;102:251-5.

36. Dell SJ, Shulman DG, Lowry GM, Howes J. A controlled evaluation of the efficacy and safety of loteprednol etabonate in the prophylactic treatment of seasonal allergic conjunctivitis. Loteprednol Allergic Conjunctivitis Study Group. Am J Ophthalmol. 1997;123:791-7.

37. Foster CS, Alter G, DeBarge LR, et al. Efficacy and safety of rimexolone $1 \%$ ophthalmic suspension vs $1 \%$ prednisolone acetate in the treatment of uveitis. Am J Ophthalmol. 1996;122:171-82.

38. Ilyas H, Slonim CB, Braswell GR, Favetta JR, Schulman M. Long-term safety of loteprednol etabonate $0.2 \%$ in the treatment of seasonal and perennial allergic conjunctivitis. Eye Contact Lens. 2004;30:10-13.

39. Noble S, Goa KL. Loteprednol etabonate: clinical potential in the management of ocular inflammation. BioDrugs. 1998;10:329-39.

40. Smith S, Lorenz D, Peace J, McLeod K, Crockett RS, Vogel R. Difluprednate ophthalmic emulsion $0.05 \%$ (Durezol) administered two times daily for managing ocular inflammation and pain following cataract surgery. Clin Ophthalmol. 2010;4:983-91.

41. Saari KM, Nelimarkka L, Ahola V, Loftsson T, Stefansson E. Comparison of topical $0.7 \%$ dexamethasone-cyclodextrin with $0.1 \%$ dexamethasone sodium phosphate for postcataract inflammation. Graefes Arch Clin Exp Ophthalmol. 2006;244:620-6.

42. Lorenz K, Dick B, Jehkul A, Auffahrt GU. Inflammatory response after phacoemulsification treated with $0.5 \%$ prednisolone acetate or vehicle. Graefes Arch Clin Exp Ophthalmol. 2008;246:1617-22.

43. Smerdon DL, Hung SO, Akingbehin T. Doubleblind controlled trial to compare anti-inflammatory effects of tolmetin $2 \%$, prednisolone $0.5 \%$, and placebo in post-cataract extraction eyes. $\mathrm{Br} \mathrm{J}$ Ophthalmol. 1986;70:761-3.

44. Trinavarat A, Atchaneeyasakul LO, Surachatkumtonekul T, Kosrirukvongs P. Comparison of topical prednisolone acetate, 
ketorolac tromethamine and fluorometholone acetate in reducing inflammation after phacoemulsification. J Med Assoc Thai. 2003;86: $143-50$.

45. Vetrugno M, Quaranta GM, Maino A, Cardia L. A randomized, comparative study of fluorometholone $0.2 \%$ and fluorometholone $0.1 \%$ acetate after photorefractive keratectomy. Eur J Ophthalmol. 2000;10:39-45.

46. Assil KK, Massry G, Lehmann R, Fox K, Stewart R. Control of ocular inflammation after cataract extraction with rimexolone 1\% ophthalmic suspension. J Cataract Refract Surg. 1997;23:750-7.

47. Fong R, Leitritz M, Siou-Mermet R, Erb T. Loteprednol etabonate gel $0.5 \%$ for postoperative pain and inflammation after cataract surgery: results of a multicenter trial. Clin Ophthalmol. 2012;6:1113-24.

48. Rajpal RK, Roel L, Siou-Mermet R, Erb T. Efficacy and safety of loteprednol etabonate $0.5 \%$ gel in the treatment of ocular inflammation and pain after cataract surgery. J Cataract Refract Surg. 2013;39:158-67.

49. Fox PK, Lewis AJ, Rae RM, Sim AW, Woods GF. The biological properties of Org 6216, a new type of steroid with a selective local anti-inflammatory action. Arzneimittelforschung. 1980;30:55-9.

50. Leibowitz HM, Bartlett JD, Rich R, McQuirter H, Stewart R, Assil K. Intraocular pressure-raising potential of $1.0 \%$ rimexolone in patients responding to corticosteroids. Arch Ophthalmol. 1996;114:933-7.

51. Yaylali V, Ozbay D, Tatlipinar S, Yildirim C, Ozden S. Efficacy and safety of rimexolone $1 \%$ versus prednisolone acetate $1 \%$ in the control of postoperative inflammation following phacoemulsification cataract surgery. Int Ophthalmol. 2004;25:65-8.

52. Kavuncu S, Horoz $\mathrm{H}$, Ardagil A, Erbil HH. Rimexolone $1 \%$ versus prednisolone acetate in preventing early postoperative inflammation after cataract surgery. Int Ophthalmol. 2008;28: 281-5.

53. Cable MM. Intraocular pressure spikes using difluprednate $0.05 \%$ for postoperative cataract inflammation. Assoc Res Vis Ophthalmol Ann Meet Abstr. 2010;51:1981.

54. Pavesio CE, Decory HH. Treatment of ocular inflammatory conditions with loteprednol etabonate. Br J Ophthalmol. 2008;92:455-9.
55. Bodor N, Buchwald P. Soft drug design: general principles and recent applications. Med Res Rev. 2000;20:58-101.

56. Comstock TL, Decory HH. Advances in corticosteroid therapy for ocular inflammation: loteprednol etabonate. Int J Inflam. 2012;2012: 789623.

57. Bielory BP, Perez VL, Bielory L. Treatment of seasonal allergic conjunctivitis with ophthalmic corticosteroids: in search of the perfect ocular corticosteroids in the treatment of allergic conjunctivitis. Curr Opin Allergy Clin Immunol. 2010;10:469-77.

58. Bodor N, Buchwald P. Ophthalmic drug design based on the metabolic activity of the eye: soft drugs and chemical delivery systems. AAPS J. 2005; 7:E820-33.

59. Comstock TL, Usner DW. Effect of loteprednol etabonate ophthalmic suspension $0.5 \%$ on postoperative pain and discomfort. In: Presentation at the American Society of Cataract and Refractive Surgery Symposium, April 9-14, 2010; Boston, MA, USA.

60. Lane SS, Holland EJ. Loteprednol etabonate 0.5\% versus prednisolone acetate $1.0 \%$ for the treatment of inflammation after cataract surgery. J Cataract Refract Surg. 2013;39:168-73.

61. Asbell P, Howes J. A double-masked, placebocontrolled evaluation of the efficacy and safety of loteprednol etabonate in the treatment of giant papillary conjunctivitis. CLAO J. 1997;23: $31-6$.

62. Friedlaender $\mathrm{MH}$, Howes J. A double-masked, placebo-controlled evaluation of the efficacy and safety of loteprednol etabonate in the treatment of giant papillary conjunctivitis. The Loteprednol Etabonate Giant Papillary Conjunctivitis Study Group I. Am J Ophthalmol. 1997;123:455-64.

63. Pflugfelder SC, Maskin SL, Anderson B, et al. A randomized, double-masked, placebo-controlled, multicenter comparison of loteprednol etabonate ophthalmic suspension, $0.5 \%$, and placebo for treatment of keratoconjunctivitis sicca in patients with delayed tear clearance. Am J Ophthalmol. 2004;138:444-57.

64. Shulman DG, Lothringer LL, Rubin JM, et al. A randomized, double-masked, placebo-controlled parallel study of loteprednol etabonate $0.2 \%$ in patients with seasonal allergic conjunctivitis. Ophthalmology. 1999;106:362-9. 
65. Chen M, Gong L, Sun X, et al. A multicenter, randomized, parallel-group, clinical trial comparing the safety and efficacy of loteprednol etabonate $0.5 \% /$ tobramycin $0.3 \%$ with dexamethasone $0.1 \%$ / tobramycin $0.3 \%$ in the treatment of Chinese patients with blepharokeratoconjunctivitis. Curr Med Res Opin. 2012;28:385-94.

66. Comstock TL, Holland EJ. Loteprednol and tobramycin in combination: a review of their impact on current treatment regimens. Expert Opin Pharmacother. 2010;11:843-52.

67. Holland EJ, Bartlett JD, Paterno MR, Usner DW, Comstock TL. Effects of loteprednol/tobramycin versus dexamethasone/tobramycin on intraocular pressure in healthy volunteers. Cornea. 2008;27:50-5.

68. White EM, Macy JI, Bateman KM, Comstock TL. Comparison of the safety and efficacy of loteprednol $\quad 0.5 \% /$ tobramycin $\quad 0.3 \%$ with dexamethasone $0.1 \%$ /tobramycin $0.3 \%$ in the treatment of blepharokeratoconjunctivitis. Curr Med Res Opin. 2008;24:287-96.
69. Novack GD, Howes J, Crockett RS, Sherwood MB. Change in intraocular pressure during long-term use of loteprednol etabonate. J Glaucoma. 1998;7:266-9.

70. Becker B. The genetic problem of chronic simple glaucoma. Ann Ophthalmol. 1971;3:351-4.

71. Becker B, Hahn KA. Topical corticosteroids and heredity in primary open-angle glaucoma. Am J Ophthalmol. 1964;57:543-51.

72. Bartlett JD, Woolley TW, Adams CM. Identification of high intraocular pressure responders to topical ophthalmic corticosteroids. J Ocul Pharmacol. 1993;9:35-45.

73. Cantrill HL, Palmberg PF, Zink HA, Waltman SR, Podos SM, Becker B. Comparison of in vitro potency of corticosteroids with ability to raise intraocular pressure. Am J Ophthalmol. 1975;79:1012-7.

74. Akingbehin AO. Comparative study of the intraocular pressure effects of fluorometholone $0.1 \%$ versus dexamethasone $0.1 \% . \mathrm{Br} \quad \mathrm{J}$ Ophthalmol. 1983;67:661-3. 